\title{
Late Ordovician (Hirnantian) scolecodont clusters from the Soom Shale Lagerstätte, South Africa
}

\author{
ROWAN WHITTLE ${ }^{1,2}$, SARAH GABBOTT $^{1}$, RICHARD ALDRIDGE $^{1} \&$ JOHANNES THERON $^{3}$ \\ ${ }^{1}$ Department of Geology, University of Leicester, Leicester LE1 7RH, UK \\ ${ }^{2}$ Current address: British Antarctic Survey, Geological Sciences Division, Madingley Road, Cambridge CB3 0ET, UK \\ ${ }^{3}$ Department of Geology, University of Stellenbosch, Private Bag XI, Stellenbosch 7602, South Africa (e-mail roit@bas.ac.uk)
}

\begin{abstract}
More than 20 partial scolecodont clusters were recovered from the Soom Shale Lagerstätte, South Africa. The specimens were found in association with chitinozoans, algae, conodont apparatuses and the enigmatic needle-like fossil Siphonacis. The Family Xanioprionidae is identified and the species Xanioprion? n. sp. is distinguished. The Family Mochtyellidae is also identified and the new genus Synaptogenys and new species S. rietvleiensis are described. The specimens represent the first described scolecodonts from South Africa and the first apparatus-based taxonomic study of specimens from Gondwana. J. Micropalaeontol. 27(2): 147-159, November 2008.
\end{abstract}

KEYWORDS: scolecodont, Polychaeta, Soom Shale, Xanioprionidae, Mochtyellidae

\section{INTRODUCTION}

Scolecodonts are the durable jaw elements of polychaete annelid worms. As the soft-body anatomy of polychaete annelids has a very low preservation potential, scolecodonts provide the best fossil record for the Polychaeta and enable reconstructions of long-lost communities and phylogeny (Hints \& Eriksson, 2007). Scolecodonts are particularly numerous in Ordovician, Silurian and Devonian deposits and are found all over the world. The oldest scolecodonts were recorded from the latest Cambrian of Newfoundland, although diversity and abundance remained very low until the Darriwilian (Hints \& Eriksson, 2007). In the late Mid-Ordovician, species- and genus-level diversity increased. Scolecodont fossils indicate that extinction rates of polychaetes were low in the Ordovician, increasing only slightly in the latest Late Ordovician (Hints \& Eriksson, 2007).

Fused polychaete jaw apparatuses (or natural assemblages) are rare in the fossil record, as they generally become disarticulated (Eriksson et al., 2004), dispersed individual jaw elements approximately $0.2-2 \mathrm{~mm}$ in size are found most commonly (Hints, 1998). The jaws are acid resistant and can be recovered in great numbers by dissolving limestones and shales (Eriksson et al., 2004). Finds of complete polychaete jaw apparatuses are important for understanding the jaw apparatus architecture. This includes identification of the number, arrangement and type of elements (Bergman, 1989). Ordovician and Silurian polychaete jaw apparatuses have been studied the most (e.g. Šnajdr, 1951; Kozłowski, 1956; Martinsson, 1960; Kielan-Jaworowska, 1961, 1962, 1966; Szaniawski, 1970; Szaniawski \& Wrona, 1973). The number of multi-element species known currently from the Ordovician rock record just exceeds 200 and the number of apparatusbased jawed polychaete genera exceeds 50, representing 15-20 families (Hints \& Eriksson, 2007).

Late Ordovician scolecodonts are known most commonly from North America (Stauffer, 1933; Eller, 1942, 1945, 1969; Eriksson, 2003; Eriksson \& Bergman, 2003), where they represent a warm-water fauna, and from Baltoscandia (Hints, 1998, 2000), where they represent a colder-water fauna. Ordovician scolecodonts are scarce from higher palaeolatitudes, such as Gondwana and the peripheral palaeoplates (cf. Eriksson et al.,
2004), and no thorough apparatus-based taxonomic studies have been published from these regions (Hints \& Eriksson, 2007). Jaw elements were recorded from the Ordovician of Australia, Iran, India, North Africa, China and France (Hints \& Eriksson, 2007). This paper describes the first scolecodonts known from South Africa, from the Soom Shale Lagerstätte, and provides the first apparatus-based descriptions of specimens from Gondwana.

\section{Scolecodont taxonomy}

The majority of the Palaeozoic scolecodonts are interpreted as belonging to polychaetes of the extant Order Eunicida (KielanJaworowska, 1966; Szaniawski, 1996; Eriksson \& Bergman, 2003), although the Order Phyllodocida has also been identified in latest Palaeozoic strata (Nakrem et al., 2001; Eriksson \& Bergman, 2003). There are five structural types of maxillary apparatus recognized within the Eunicida, based on the arrangement of elements and their number and shape; these are labidognath, prionognath, placognath, ctenognath and xenognath types (Ehlers, 1864-8, Kielan-Jaworowska, 1966; Mierzejewski \& Mierzejewska, 1975; Szaniawski, 1996; Eriksson et al., 2004) (Fig. 1). In addition to these five distinctive types, some intermediate forms have been recognized (KielanJaworowska, 1966; Hints, 1999; Eriksson et al., 2004). These different structural types of apparatus do not correspond strictly to taxonomic units but they are useful for inferring evolutionary patterns (Kielan-Jaworowska, 1966; Szaniawski, 1996; Eriksson et al., 2004). The earliest known fossil scolecodonts have primitive, usually symmetrical jaw apparatus architecture of placognath and/or ctenognath type (Hints \& Eriksson, 2007). The two taxa described from the Soom Shale are of placognath type.

The buccal armature of most eunicidans is composed of one pair of ventral mandibles and a multi-element, dorsal maxillary apparatus (Szaniawski, 1996). The maxillary apparatus comprises a number of maxillae (abbreviated $\mathrm{M}$ ), which are generally paired and numbered in roman numerals from posterior to anterior (Kielan-Jaworowska, 1966). Also, a basal plate may be present close to the right MI (first maxilla in right position), and 


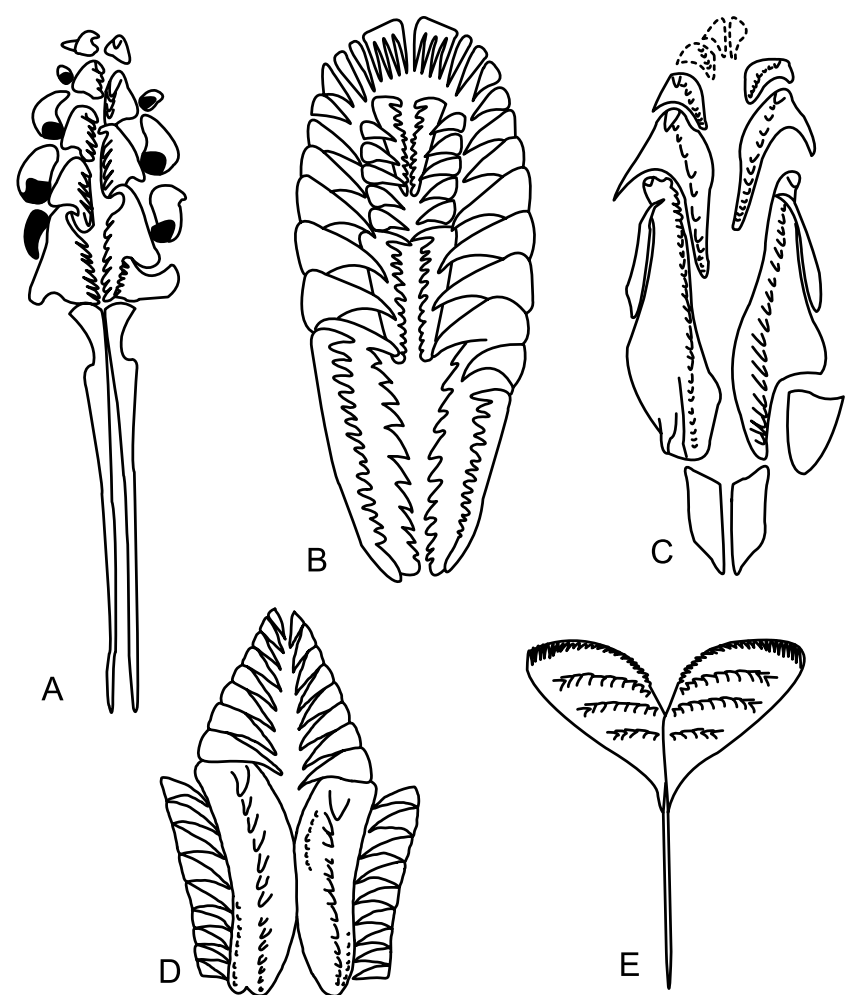

Fig. 1. The five different types of eunicidan maxillary apparatus (from Kielan-Jaworowska, 1966; Mierzejewski \& Mierzejewska, 1975; Szaniawski, 1996; Glasby et al., 2000; Eriksson et al., 2004). (A) Prionognath type; Oenone fulgida (Savigny, in Lamarck, 1818). (B) Ctenognath type; Tetraprion pozaryskae Kielan-Jaworowska, 1966. (C) Labidognath type; Ramphoprion elongatus Kielan-Jaworowska, 1962. (D) Placognath type; Mochtyella polonica Kielan-Jaworowska, 1966. (E) Xenognath type; Archaeoprion quadricristatus Mierzejewski \& Mierzejewska, 1975.

a laeobasal plate close to the left MI (first maxilla in left position). Minor supporting jaws, such as lateral teeth (Lt) (Figs 2A, 3B) and an intercalary tooth (It), may be present (Kielan-Jaworowska, 1966; Eriksson et al., 2004).

Some forms can have more than one ridge (which is smooth or denticulated) on the MI and these are known as compound jaws. Those with one ridge of denticles are known as simple jaws. Ridges on the right MI are referred to as the main ridge (mr), basal ridge (br) and second ridge (sr) (Fig. 2A). These ridges are interpreted as being homologous to the MI, basal plate and MII, respectively of the more advanced apparatuses (Kielan-Jaworowska, 1966). On the left MI jaw there are the main ridge and laeobasal ridge, thought to be homologous to the left MI and laeobasal plate of more advanced groups (Kielan-Jaworowska, 1966) (Fig. 2A).

\section{Distribution and ecology}

Some species of polychaetes are eurytopic, tolerating different environments. For example, members of the extant Family Onuphidae are found in all the oceans of the world and at all depths (Glasby \& Alvarez, 1999). Others are stenotopic, flourishing in specialized environments (Bergman, 1989, 1995; Hints, 2000; Eriksson, 2001; Eriksson \& Bergman, 2003); for example, most paulinitid species show a preference for a particular habitat, with the highest diversity of faunas in relatively shallow, sheltered lagoonal environments (Bergman, 1989). Some have a limited geographical and depth distribution (Paxton, 1986; Eriksson et al., 2004) and are very sensitive to facies type (Szaniawski, 1996). Based on current knowledge, most fossil species are restricted respectively to one palaeocontinent only (Hints \& Eriksson, 2007).

The majority of the Recent Eunicida live in shallowwater sediments, especially near shore, but some are pelagic (Szaniawski, 1996). Fossil jawed polychaetes were facies controlled in their distribution; the abundance and taxonomic diversity of scolecodonts increases with decreasing depositional depth, this is because shallower-water environments provided more suitable living conditions than deeper ones (Bergman, 1979, 1989; Eriksson, 1997; Hints, 2000; Eriksson \& Bergman, 2003). Although water depth was presumably the primary influence on polychaete distribution, other controlling factors, such as temperature, light, salinity, turbidity and access of nutrients, which are commonly correlated to water depth, may have been important (Eriksson \& Bergman, 2003).

\section{Geological setting}

The Late Ordovician Soom Shale Konservat-Lagerstätte is located in the Cedarberg Mountains, north of Cape Town. An exceptionally preserved soft-bodied fauna was recovered from several localities (Gabbott et al., 1995; Gabbott, 1998; Aldridge et al., 2001) (Fig. 4).

Reconstructions of Late Ordovician continental palaeogeography locate South Africa at between about $30^{\circ}$ and $45^{\circ} \mathrm{S}$ (Fig. 5) (Beuf et al., 1971; Smith, 1997; Sutcliffe et al., 2000; Cocks \& Torsvik, 2002; Fortey \& Cocks, 2003; Young et al., 2004). The Soom Shale was deposited in the Hirnantian (Sutcliffe et al., 2000; Young et al., 2004) and is the lower member of the Cedarberg Formation, which, in turn, is part of the Table Mountain Group. The Soom Shale mainly consists of mud and siltstone, totalling $10-15 \mathrm{~m}$ in thickness. The overlying Disa Member, the upper part of the Cedarberg Formation, is composed of micaceous siltstone (Fig. 6) (Gray et al., 1986).

The Soom Shale was deposited in quiet marine conditions (Aldridge et al., 2001). The laminated fine-grained lithology shows very little evidence of water turbulence or bioturbation (Gabbott et al., 2003). It is thought that the water depth was about $100 \mathrm{~m}$ across the majority of the basin; bottom waters in the basin may have been quite cool (Gabbott, 1998). The sediment pore waters were largely anoxic; geochemical analyses indicate that euxinic bottom waters may have prevailed at times (Gabbott, 1998).

Cool, anoxic waters were thought to have contributed to the exceptional preservation of some fossil material in the Soom Shale. Non-mineralized anatomy is preserved as organic films, or as authigenic clay mineral replacements (Gabbott, 1998; Gabbott et al., 2001). Original biominerals, for example aragonite, calcite and apatite, were dissolved completely, leaving moulds that have been subsequently compacted (Gabbott, 1998; Gabbott et al., 2001). Some fossils, for example the arthropod Caryocaris, show several different preservation styles on a single specimen, including organic material and a clay mineral coating that is either authigenic, diagenetic or metamorphic (Whittle et al., 2007). 


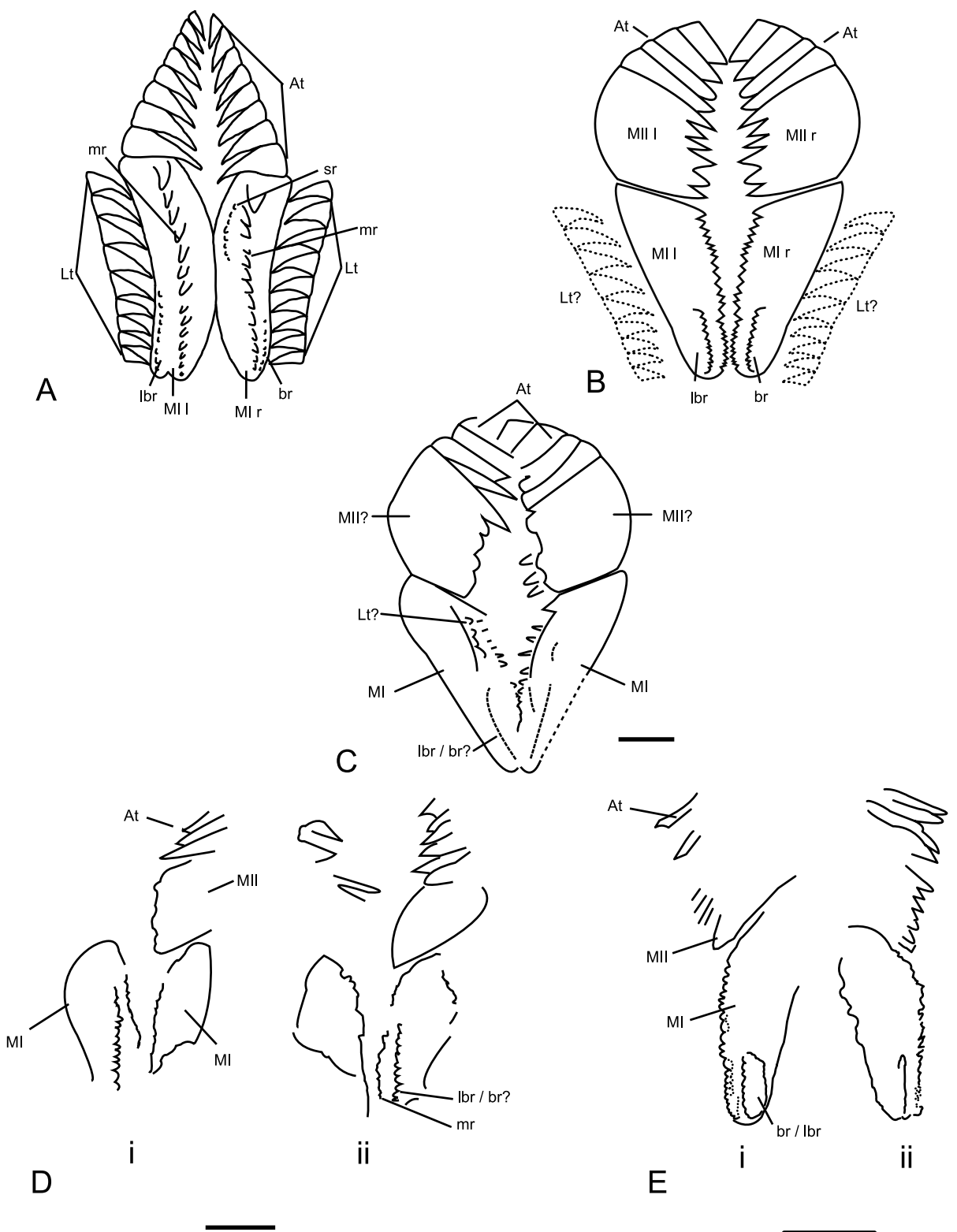

Fig. 2. Mochtyellid maxillary apparatuses, showing the arrangement and numbering of the jaws. (A) Mochtyella polonica (from Kielan-Jaworowska, 1966). (B) Synaptogenys rietvleiensis n. gen., n. sp.; the reconstruction is based on several specimens. (C-E) Camera lucida drawings of the mochtyellid apparatuses identified as Synaptogenys rietvleiensis n. gen., n. sp. from the Soom Shale: (C) C853b (counterpart); (D) i, C2021a (part), ii, C2021b (counterpart); (E) i, C2030a (part), ii, C2030b (counterpart). Abbreviations: At, anterior teeth; br, basal ridge; lbr, laeobasal ridge; Lt, lateral teeth; MI 1, first maxilla left; MII 1, second maxilla left; MI r, first maxilla right; MII r, second maxilla right; mr, main ridge; sr, second ridge. Scale bars in $\mathrm{C}$ and $\mathrm{D}=0.25 \mathrm{~mm}$ and in $\mathrm{E}=0.5 \mathrm{~mm}$.

\section{MATERIALS AND METHODS}

The repository of the specimens (prefixed C) used in this study is the Council of Geosciences of South Africa, Bellville. They originated from Keurbos Quarry $\left(18^{\circ} 58^{\prime} \mathrm{E}, 32^{\circ} 16^{\prime} \mathrm{S}\right)$ near to the town of Clanwilliam, South Africa (Fig. 4). Twenty-two partial polychaete jaw apparatuses were identified in differing states of preservation. Most specimens represent only two jaw elements, whereas others are much more complete.

The fossils were studied using an optical microscope, drawn with the aid of a camera lucida, and photographed using a digital camera and Scanning Electron Microscope (Hitachi S-3600N). Analysis was carried out with scanning electron microscope energy dispersive X-rays (SEM EDX) using an Oxford Instruments detector. For SEM EDX analysis, uncoated material was used in partial vacuum mode at $15 \mathrm{kV}$. Elemental mapping was used to show the relative abundance of elements in different areas of the fossils and the sediment. EDX point analyses allowed the composition of very small areas (approximately 3-4 $\mu \mathrm{m}$ ) to be determined.

\section{PRESERVATION OF SPECIMENS}

It is thought that polychaete jaws are formed through thickening and hardening of pharyngeal cuticle (Szaniawski, 1996). The jaws of polychaetes are composed mainly of scleroprotein, with 


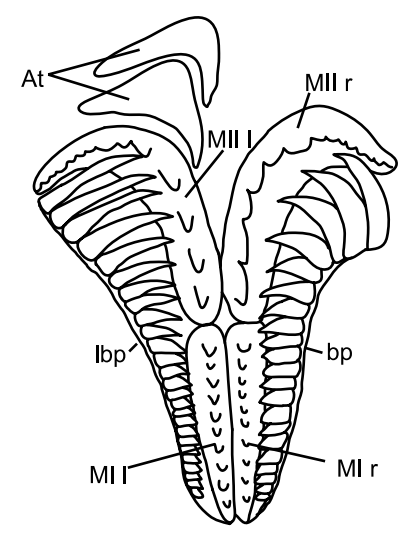

A

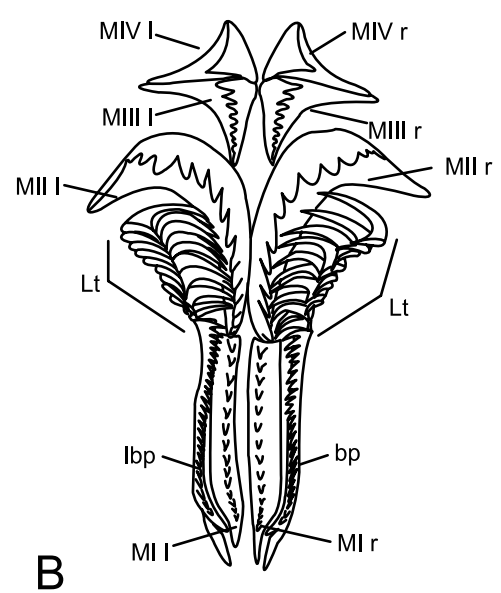

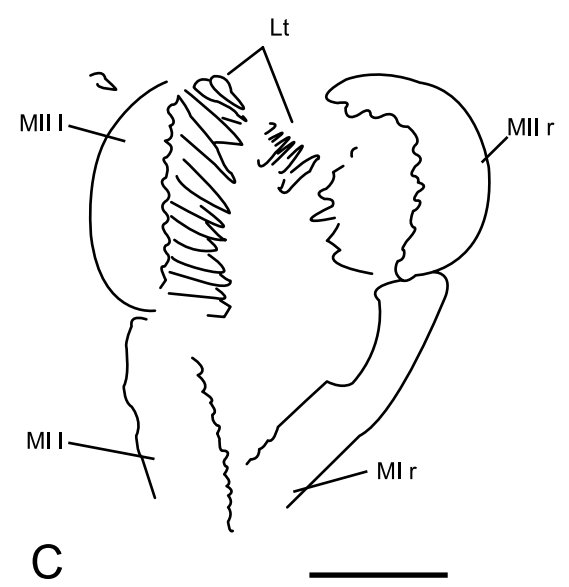

Fig. 3. Xanioprionid maxillary apparatuses, showing the arrangement and numbering of the jaws. (A) Xanioprion borealis (from Kielan-Jaworowska, 1966). (B) Xanioprion walliseri (from Szaniawski \& Wrona, 1973). (C) Specimen C319a identified as Xanioprion? n. sp. from the Soom Shale. Scale bar $=0.5 \mathrm{~mm}$. Abbreviations: bp, basal plate; lbp, laeobasal plate; MIII r, third maxilla right; MIII 1, third maxilla left; MIV r, fourth maxilla right; MIV 1, fourth maxilla left. For other abbreviations, see Figure 2.

only trace amounts of chitin (Voss-Foucart et al., 1973; Szaniawski, 1996). The amino acid composition of the proteins differs between taxa, and the degree of sclerotization of the protein also varies greatly (Szaniawski, 1996). The preservation of scolecodonts ranges from deformed, flattened and fragmented specimens, to exquisitely three-dimensionally preserved ones, with a glossy appearance, showing original morphology and micro-ornamentations (Eriksson et al., 2004).

The Soom Shale specimens occur flattened, degraded and often fragmented on bedding surfaces. Many of the diagnostic features, such as the size and shape of denticles, are not preserved. EDX analysis of scolecodont specimens produced peaks consistent with carbon (seen clearly as the black areas on the fossils in hand specimen and under the SEM in backscatter mode; Figs 7A, B) and clay minerals (white when seen in hand specimen and identical in colour to the sediment under SEM backscatter; Figs 7A, C). Where a specimen has a composition of carbon on the part, a composition of clay minerals only is seen on the counterpart of that same specimen (Pl. 1, figs 8, 9; Pl. 2, figs 12, 13). Some specimens have positive relief on the part (for example C319a) and negative relief on the counterpart (C319b) (Pl. 1, figs 1, 2). This style of preservation is found for several other Soom Shale fossils, for example conodont eye capsules and chitinozoans, where it appears that the clays have coated the surface of the organic substrate (Gabbott et al., 1998; Aldridge et al., 2001). Occasionally, the clay minerals have a slightly fibrous texture. This may relate to the way in which it originally grew when it replicated the fossil, or may have been created by the subsequent metamorphism of the fossils (Whittle et al., 2007).

The easiest method of processing samples for scolecodonts is to dissolve rock in acid. Scolecodonts are often present in samples processed for palynological or conodont investigations (Szaniawski, 1996). Cramer et al. (1974) processed rock samples using acid digestion, primarily to identify chitinozoans from the Soom Shale but these yielded no scolecodont specimens when restudied. This is not surprising as the carbon on the scolecodont specimens is cracked into a mosaic-like appearance (Fig. 7A); this is likely to be related to the dehydration of the fossil during diagenesis and/or metamorphism. Upon acid treatment, this carbon would break up into unidentifiable fragments. Also, as parts of the specimens exhibit a clay mineral composition and the sediment is also composed of clay minerals, traditional extraction methods will not yield scolecodonts at this site. The number of scolecodonts from the Soom Shale may be underestimated vastly because the specimens are small (1-2 mm) 


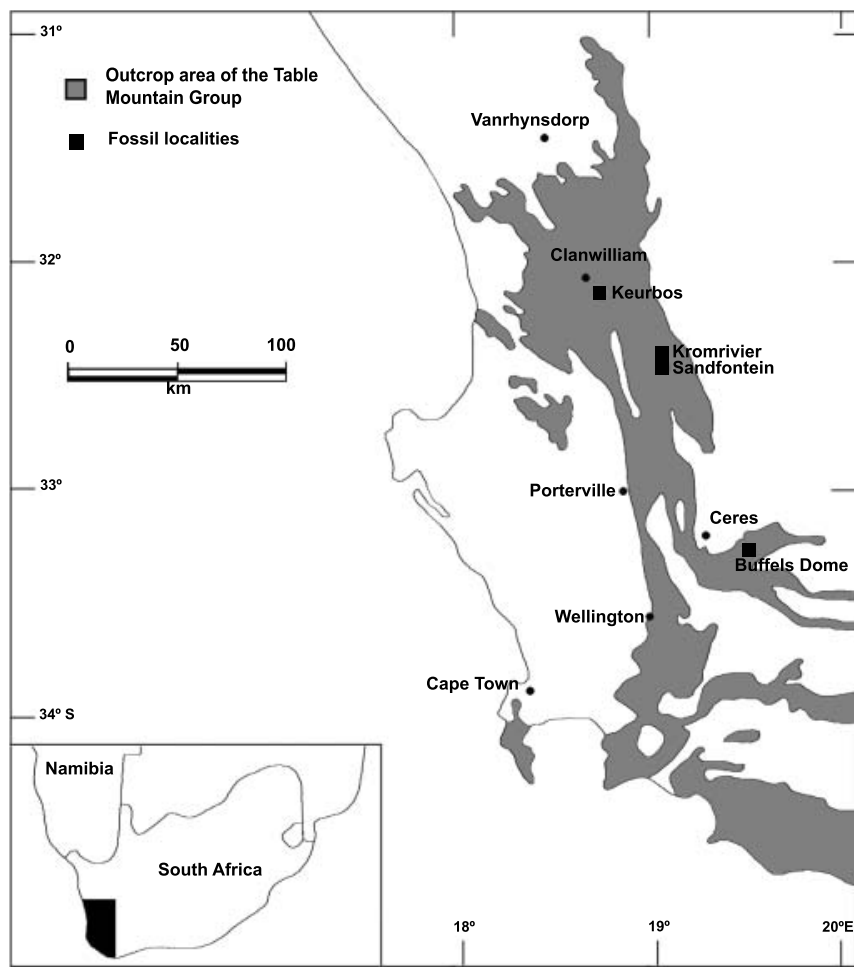

Fig. 4. Outcrop of the Table Mountain Group in southwestern South Africa, showing the location of the fossiliferous exposures of the Soom Shale (from Gabbott et al., 2003). Scolecodont clusters were found at Keurbos Quarry, near to the town of Clanwilliam.

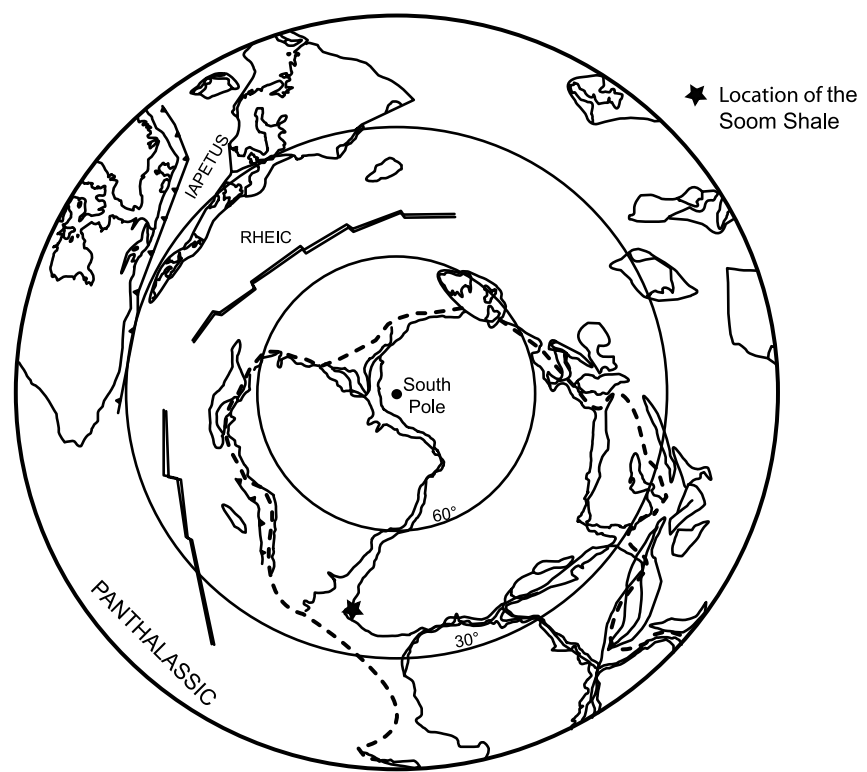

Fig. 5. A global reconstruction for the end of the Ordovician/beginning of the Silurian (440 Ma), with the location of the Soom Shale Lagerstätte (reconstruction from Fortey \& Cocks, 2003; modified from Cocks \& Torsvik, 2002).

compared to most other Soom Shale fossils, and are often sediment coloured, so they may not be recognized during collecting.

\section{THE SOOM SHALE SCOLECODONT FAUNA}

The Soom Shale polychaete fauna appears to include representatives of two main taxa, the Families Mochtyellidae and Xanioprionidae. Some of the more complete apparatuses exhibit novel features not found in currently known genera and thus a new genus and new species must be established for them.

Specimens assigned to the placognath Family Mochtyellidae exhibit compound posterior jaws and free anterior teeth (Fig. 2). However, several Soom Shale specimens, although they have compound posterior jaws and free anterior-most teeth, also have a pair of MII anterior of the MI (Figs 2B-E), and thus a new genus is erected to incorporate them. A selection of specimens, where only a single $\mathrm{MI}$ is preserved, are placed in the Mochtyellidae, based on the compound nature of this jaw (Figs 2D, E); compound jaws are generally found in primitive forms, such as the placognath Mochtyella (Kielan-Jaworowska, 1966; Szaniawski, 1996). Placognath scolecodonts have rows of anterior teeth, clearly seen in many of the specimens (e.g. C853) (Fig. 2; P1. 2). Finally, the Soom Shale specimens are identified as belonging to the Family Mochtyellidae because the overall morphology of the MI is very similar to that of other members of the family.

The mochtyellid specimens from the Soom Shale all have MI preserved; these may occur with MII and anterior teeth, or the MII and anterior teeth may be badly degraded or completely missing. There is no instance where the MII and anterior teeth are found preserved without the MI. Within the fauna, 14 specimens were identified as possibly belonging to the Family Mochtyellidae, making this the most abundant scolecodont family in the Soom Shale.

The Soom Shale Xanioprionidae were assigned based upon the long thin nature of the MI and the arcuate MII (Fig. 3). In the Xanioprionidae the MII have a strong outward curvature and are similar in outline to each other (Kielan-Jaworowska, 1966; Edgar, 1984). Three clusters from the Soom Shale with MI and MII still attached were identified as belonging to the Family Xanioprionidae. One of these specimens (unfigured) has arcuate MII, with the anterior of the elements pointing outwards and can be assigned to the Genus Xanioprion. However, two of the specimens exhibit arcuate MII, with the anterior of the elements pointing inwards (C319 and C1976) (Fig. 3C; P1. 1); this feature has not been documented before and therefore these specimens are assigned to Xanioprion? n. sp. described below. C319 and possibly C1976 have a string of lateral teeth (Fig. 3; Pl. 1), and a further (unfigured) specimen may represent the lateral teeth preserved alone. Therefore, the number of specimens that belong to the Family Xanioprionidae currently recovered from the Soom Shale is possibly four.

\section{SYSTEMATIC DESCRIPTIONS \\ Class Polychaeta Grube, 1850 \\ Order Eunicida Dales, 1963}

Family Xanioprionidae Kielan-Jaworowska, 1966

\section{Diagnosis.}

"Symmetrical jaw apparatuses of placognatha type. Carriers lacking; MI elongated longitudinally, subrectangular; MII arcuate, large jaws, arranged in front of $\mathrm{MI}$; basal and 


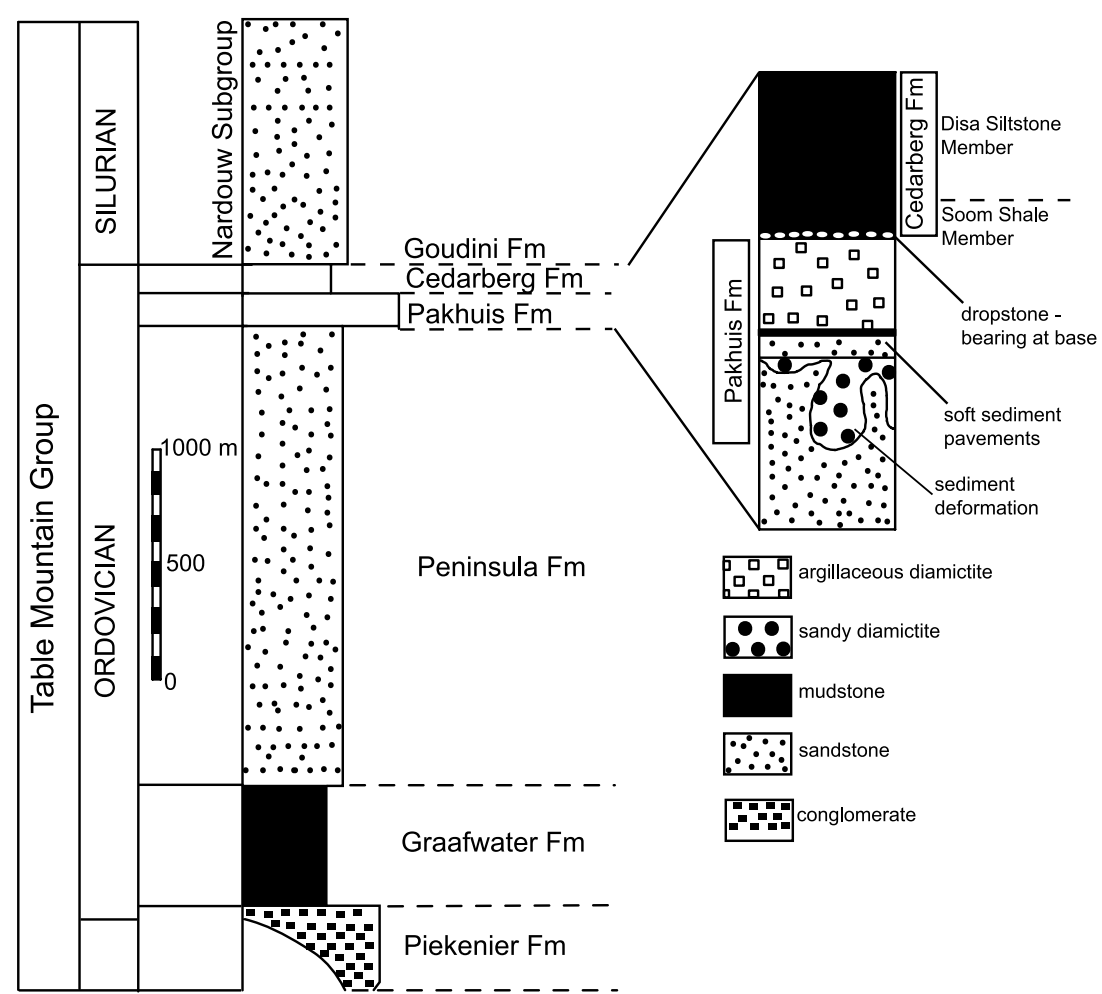

Fig. 6. Generalized stratigraphy of the Table Mountain Group. Expanded column (not to scale) shows the stratigraphical relationships between the Pakhuis and Cedarberg formations, and the position of the Soom Shale and Disa Siltstone members (modified from Young et al., 2004; after Theron \& Thamm, 1990).

laeobasal plates strongly elongated, consisting of numerous denticles which are very long in anterior part, decreasing in size posteriorly. Basal and laeobasal plates adhere to the outer margins of MI and MII covering them dorsally. In front of MII an unestablished number of anterior teeth are present (Kielan-Jaworowska, 1966, p. 64)."

?Genus Xanioprion Kielan-Jaworowska, 1962

Type species. Xanioprion borealis Kielan-Jaworowska, 1962 from a mid- or Late Ordovician age erratic boulder, Poland.

\section{Diagnosis.}

"Nearly symmetrical jaw apparatuses consisting of three jaws, some lateral teeth and one or more anterior teeth on each side. MI straight, subrectangular. MII arcuate, larger than MI and arranged in front of them. Laeobasal and basal plates finely denticulated with denticles decreasing posteriorly in size. Pulp cavity of laeobasal and basal plates narrowly open. MIII subtriangular, finely denticulated. Lateral teeth arcuate, long, sharply pointed. Anterior teeth (or MIV) arranged in front of MIII, subtriangular in outline."

Emended diagnosis by Szaniawski \& Wrona (1973, p. 236), after Kielan-Jaworowska (1962).

Xanioprion? n. sp.

(Fig. 3C; Pl. 1, figs 1-11)
Material. C319a and b (part and counterpart) and C1976a and b (part and counterpart).

Locality and horizon. Keurbos Quarry $\left(18^{\circ} 58^{\prime} \mathrm{E}, 32^{\circ} 16^{\prime} \mathrm{S}\right)$, near Clanwilliam, South Africa. Soom Shale Member, Cedarberg Formation, Table Mountain Group (Fig. 4).

Age. Late Ordovician (Hirnantian).

Description. Apparatus almost symmetrical. Approximate maximum length of apparatus (C319, incomplete) $1.6 \mathrm{~mm}$, maximum width $1.3 \mathrm{~mm}$. Apparatus consists of right and left MI, right and left MII situated anteriorly of MI, and a string of probable lateral teeth. Elongate MI, nearly straight, composed of a row of approximately 14 denticles (C319), relative size of which cannot be determined due to degradation. MII are clearly arcuate, pointing anteriorly towards centre of apparatus. Tips of denticles are not evident, but there are approximately 9-10 visible (C319).

In C319, right MI length $1 \mathrm{~mm}$, width approximately $0.2 \mathrm{~mm}$ (tips of denticles missing). Incomplete left MI at least $0.76 \mathrm{~mm}$ in length, width $0.26 \mathrm{~mm}$ (tips of denticles missing). C319 Right MII length at least $0.7 \mathrm{~mm}$, width $0.23 \mathrm{~mm}$ (tips of denticles missing). Incomplete left MII (anterior end missing) length at least $0.76 \mathrm{~mm}$, width approximately $0.36 \mathrm{~mm}$ (to tips of denticles) (Fig. 3C; P1. 1). C1976 consists of partial right MI and MII, left MI and MII are not preserved clearly.

C319 and possibly C1976 both have a string of large centrally positioned teeth, which are possibly lateral teeth, as they appear 

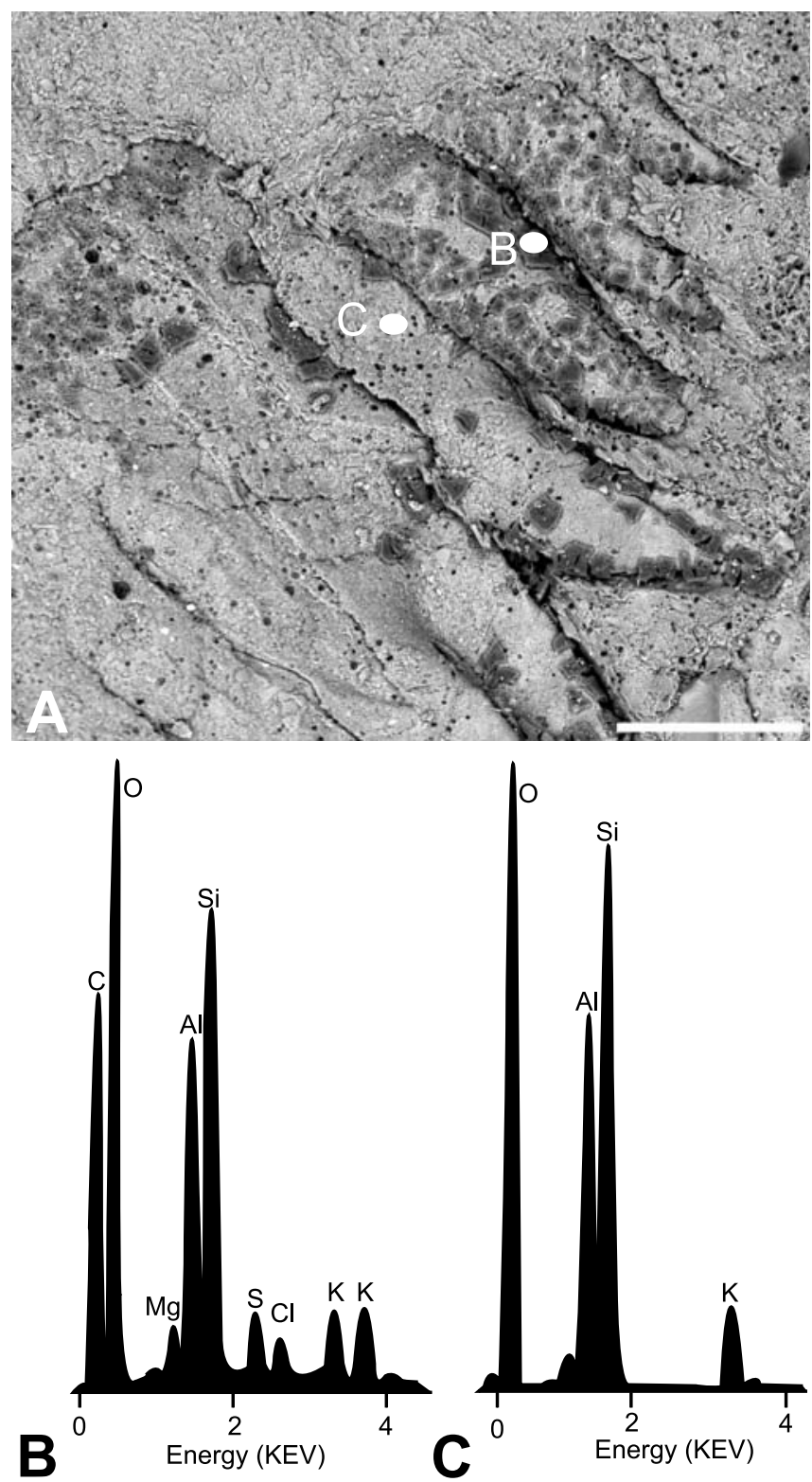

Fig. 7. (A) SEM image of part of scolecodont cluster C319a, from where the EDX analyses shown in (B) and (C) were taken. The carbon shows up clearly under backscatter mode because it is compositionally distinct from the sediment. Scale bar $100 \mu \mathrm{m}$. (B) The analysis shows a carbon composition; a clay mineral composition is also present, which may be due to beam overlap or beam penetration through the carbon. Therefore, dark areas on the scolecodont specimens have a carbon composition. (C) A clay mineral composition is indicated, this composition is found on the specimens in areas that appear white when seen with the naked eye.

to be associated with the MII, 15 visible on the left-hand side of C319 (Pl. 1, fig. 5). These long elongate lateral teeth adjoin one another very closely and vary in length, smaller anteriorly becoming longer medially. Lateral tooth series appears to sit ventrally to MII, where they are seen emerging towards the centre of the jaw apparatus (Fig. 3C; Pl. 1). The apparatus in C319 is seen in dorsal view because the denticles are evident. In ventral view, only denticle pits are evident on the maxillae of Xanioprion (e.g. Szaniawski \& Wrona, 1973, pl. II 3b, 2b).
Remarks. The specimens were assigned to the Family Xanioprionidae and tentatively to the Genus Xanioprion because they exhibit a nearly symmetrical placognath-type jaw apparatus, with longitudinally elongate MI and MII that are arcuate. When establishing the genus, Kielan-Jaworowska (1962) stated that the MIII (subsequently renamed MII, Kielan-Jaworowska, 1966) is bent outwards anteriorly. The MII of Xanioprion? n. sp. differ from those of other members of the genus in this respect as they exhibit an inward curvature (Fig. 3). The basal and laeobasal plates are not evident in the Soom Shale specimens; normally these adhere to the outer margins of the MI (Szaniawski \& Wrona, 1973). When seen in dorsal view, the possible lateral teeth appear to be located ventrally to, and along the length of, the MII in the Soom Shale specimens (Fig. 3C; Pl. 1, figs 1, 3, 5, 7), as are lateral teeth in $X$. walliseri Szaniawski \& Wrona, 1973. However, these teeth differ in Xanioprion? n. sp. because they appear to be placed centrally in the apparatus as opposed to laterally (Fig. 3C; Pl. 1, fig. 1). The Xanioprionidae exhibit characters considered to be primitive, including a gaping myocoele, one denticulated ridge per maxilla and a symmetrical jaw arrangement in the apparatus (Hints \& Eriksson, 2007).

Family Mochtyellidae Kielan-Jaworowska, 1966

\section{Diagnosis.}

"Asymmetrical jaw apparatuses of placognath type, consisting of jaws with gaping openings of the pulp cavities in the posterior part and two rows of teeth in the anterior part. Series of lateral teeth forming two chains on both sides of the posterior part of the apparatus are, as a rule, present. Carriers lacking. Basal and laeobasal plates are elongated jaws, shorter (long.) than MI; MII if present is single right. Intercalary and laeointercalary teeth sometimes present (Kielan-Jaworowska, 1966, p. 53)."

\section{Genus Synaptogenys n. gen.}

Type species. Synaptogenys rietvleiensis, by monotypy herein defined.

Derivation of name. Gr. synaptos - joined together; genys - jaw, on account of the MII.

Diagnosis. Jaw apparatus consisting of two compound jaws in the posterior part. Right and left MI provided with two ridges of denticles: laeobasal/basal ridge and main ridge, both denticulated. Chains of lateral teeth possibly covering MI dorsally. Large jaws, designated MII, present anterior of MI on both the left and right side of the apparatus, with approximately five denticles. Anterior teeth free, consisting of approximately 4-5 pairs (Fig. 2B).

Remarks. The MI bear a resemblance to those of the Genus Mochtyella in the presence of compound ridges (seen clearly on C2030, P1. 2, figs 12-15) and, if seen only as isolated elements, would possibly have been placed within this genus. The Genus Mochtyella has free anterior teeth (Fig. 2A) (KielanJaworowska, 1966), as does Synaptogenys, but Synaptogenys differs from Mochtyella in having large jaw elements anterior of MI, big enough to be designated MII. 

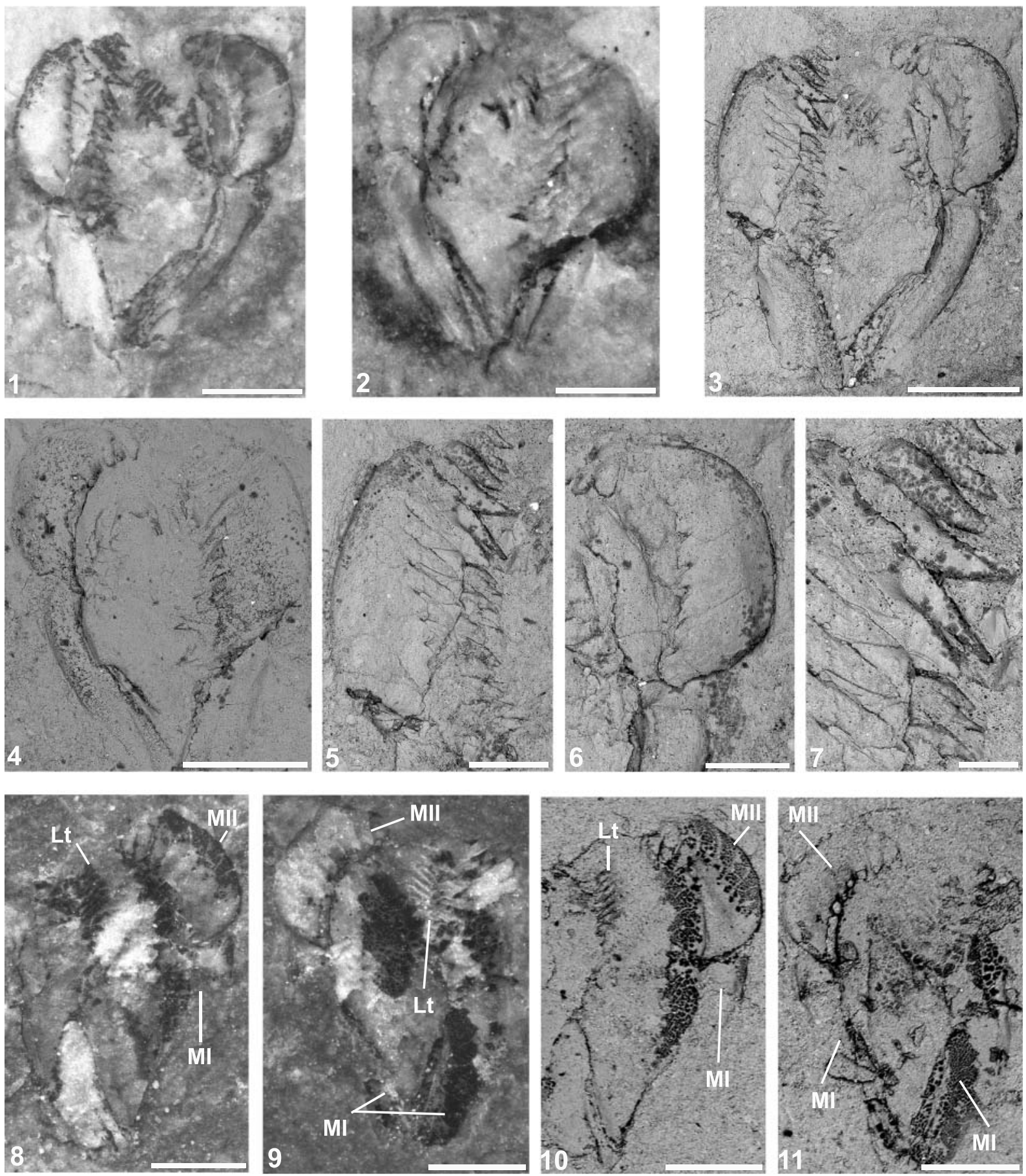

Explanation of Plate 1.

figs 1-11. The xanioprionid Xanioprion? n. sp. from the Soom Shale: 1, photograph of C319a; 2, photograph of C319b, mostly preserved in negative relief; 3-7, SEM backscattered electron images - (3) C319a, (4) C319b, (5) C319a enlargement of left MII and possible lateral teeth, (6) C319a enlargement of right MII showing the clear arcuate nature of this jaw, (7) C319a enlargement of possible lateral teeth, which are ventral to the left MII; 8, 9, photographs of C1976a (part) and b (counterpart), respectively, MI plus arcuate MII and parts of possible lateral teeth visible; where the specimen has a composition of carbon (plus clay minerals) on the part (black areas), a composition of clay minerals only is seen on the counterpart (white areas); 10, SEM backscattered electron image of C1976a; 11, SEM backscattered electron image of C1976b, MI and arcuate MII jaw clear. Abbreviations: MI, first maxilla; MII, second maxilla; Lt, lateral teeth. Scale bars in $1-4=0.5 \mathrm{~mm}, 5 \mathrm{and} 6=0.25 \mathrm{~mm}, 7=0.1 \mathrm{~mm}$ and $8-11=0.5 \mathrm{~mm}$. 
Ordovician scolecodont clusters, Soom Shale
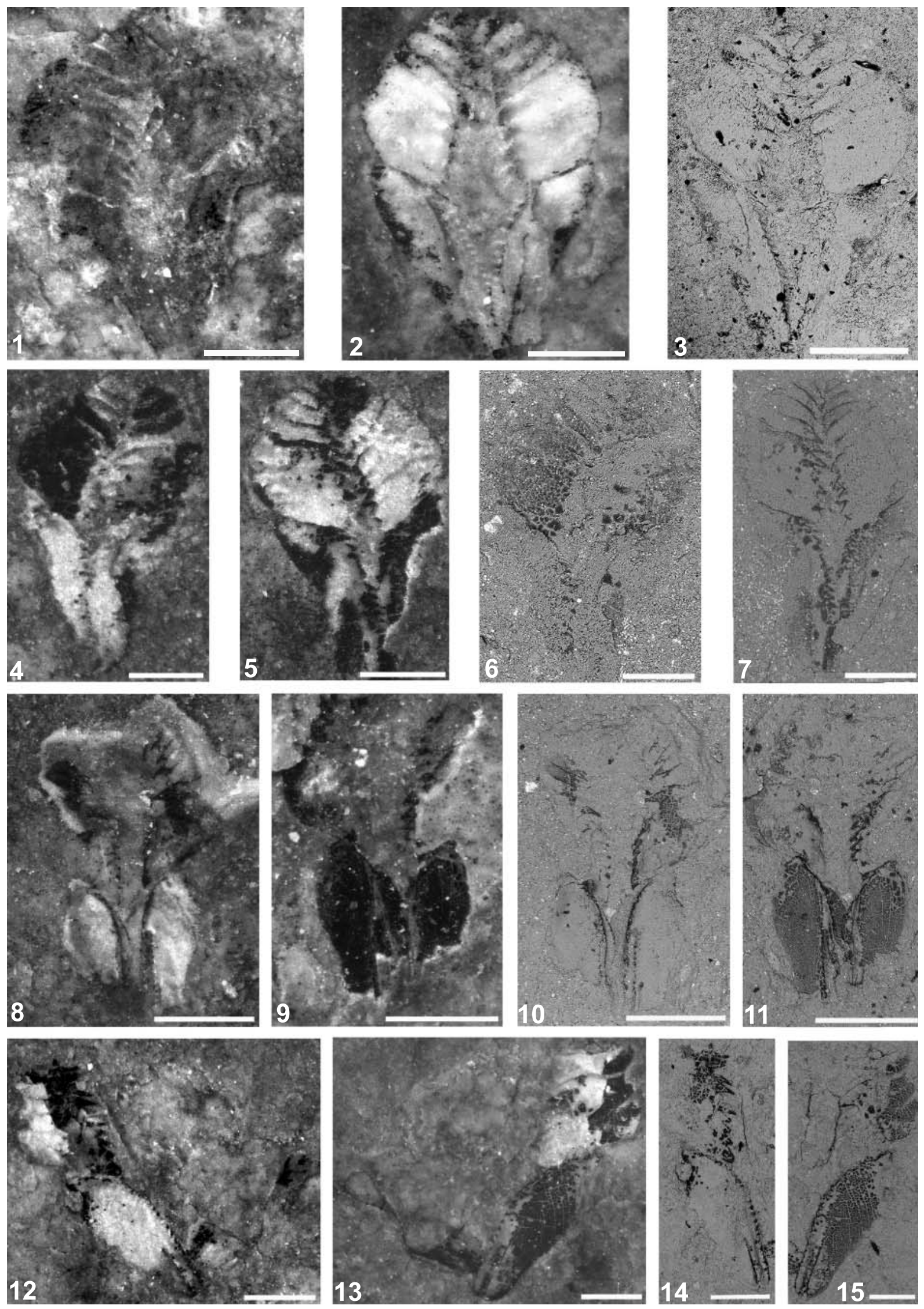
It is thought that the three ridges on the right MI of the apparatus in compound genera, such as Mochtyella, are homologous to the right MI, the basal plate and the single MII of more advanced polychaete taxa, such as the Genus Pistoprion (Kielan-Jaworowska, 1966). The main ridge and the laeobasal ridge on the left-hand side of the apparatus are thought to be homologous to the left MI and the laoebasal plate (KielanJaworowska, 1966) and there is no left-hand side MII. Therefore, the overall structure of the apparatus is asymmetrical. In Synaptogenys the posterior-most anterior teeth appear fused, forming the MII on both sides of the apparatus. This is in conflict with the hypothesis that the MI right second ridge separated to form a single MII on the right-hand side of the apparatus. The presence of the MII on both sides of the apparatus in Synaptogenys means that the overall shape of the apparatus is symmetrical. Symmetrical jaw apparatuses, such as those seen in the Family Xanioprionidae, are generally considered to be primitive (Hints \& Eriksson, 2007). If the symmetrical jaw apparatus of $S$. rietvleiensis is considered primitive, it indicates that the anterior teeth evolved to become free from an ancestor with fused teeth. Then, subsequently the compound ridges separated to form individual elements in more advanced groups. The MII in the Genus Synaptogenys are not homologous to the single MII in more derived apparatuses. Synaptogenys differs from all other genera in the Family Mochtyellidae because it has large, paired MII with several denticles, rather than one single right MII.

The feature of large MII in Synaptogenys and a symmetrical apparatus may indicate that the diagnosis of the Family Mochtyellidae needs to be amended, or that Synaptogenys should be placed within a new family. However, the overall shape of the MI is very similar to that of other mochtyellids and thus Synaptogenys has been placed within this family. With so few specimens, in which not all features are clear, it is premature to amend the well-established diagnosis for mochtyellids of Kielan-Jaworowska (1966).

\section{Synaptogenys rietvleiensis $\mathrm{n} . \mathrm{sp}$.}

(Figs 2B-E; Pl. 2, figs 1-15)

Derivation of name. After Rietvlei in the Cedarberg Mountains, South Africa.

Diagnosis. As for genus.

Holotype. C853a and b (part and counterpart) (Fig. 2C; Pl. 2, figs 1-3)

Paratype. C2030a and b (part and counterpart) (Fig. 2E; Pl. 2, figs 12-15)
Other material. C1948a, b and C2021a, b.

Locality and horizon. Keurbos Quarry, near Clanwilliam, South Africa $\left(18^{\circ} 58^{\prime} \mathrm{E}, 32^{\circ} 16^{\prime} \mathrm{S}\right)$. Soom Shale Member, Cedarberg Formation, Table Mountain Group (Fig. 4).

Age. Late Ordovician (Hirnantian)

Description. Symmetrical jaw apparatus, approximately $1.7 \mathrm{~mm}$ in total length and $1.1 \mathrm{~mm}$ total width (C853). Holotype consists of right and left MI, right and left MII, free anterior teeth and possible lateral teeth. Paratype of single MI, part of single MII and some free anterior teeth.

MI sub-rectangular; C853 right MI element length $0.9 \mathrm{~mm}$, width $0.24 \mathrm{~mm}$ (tips of denticles missing); left MI length $1.03 \mathrm{~mm}$, width $0.27 \mathrm{~mm}$ (tips of denticles missing). MI consisting of main ridge and either basal (MI right), or laeobasal (MI left) compound ridge. Denticles of MI main ridge decrease in size posteriorly; on $\mathrm{C} 2030 \mathrm{~b}$ there are at least 19 individual denticles. Compound ridge appears towards posterior of MI, seen clearly in $\mathrm{C} 2030$ b. Basal or laeobasal ridge denticulated in this specimen, consisting of approximately nine small denticles. Anterior margin of MI (right and left) directed posteriomedially, posterior margin of MI (right and left) rounded.

Anterior of MI, on the right and left side of the apparatus, there are relatively large, sub-quadrate elements designated here as MII (length and width approximately $0.52 \mathrm{~mm}$, tips of denticles missing, measured on C853). On C853, the MII each have approximately 6-7 denticles. Anterior of the MII there are some free anterior teeth, approximately 3-4 in number on C853. On specimen C853 there are four triangular, possibly lateral, teeth covering the anterior part of MI left (Fig. 2C; P1. 2, fig. 2).

Remarks. Posterior elements of Synaptogenys rietvleiensis are especially similar in morphology to those of $M$. trapezoidea Kielan-Jaworowska, 1966, as both exhibit compound ridges, laeobasal and main ridges on the left MI, and basal and main ridges on the right MI. In addition, the MI of $M$. trapezoidea and $S$. rietvleiensis both have a straight anterior margin, directed postero-medially and a rounded posterior margin. However, $S$. rietvleiensis differs from $M$. trapezoidea due to the presence of paired MII.

\section{PALAEOECOLOGICAL IMPLICATIONS}

The recognition of scolecodonts in the Late Ordovician Soom Shale Lagerstätte increases the geographical range of the Mochtyellidae and the Xanioprionidae to include the marginal Gondwanan continent region. Some scolecodont-bearing species are common to many locations, for example from the margins of

Explanation of Plate 2.

figs 1-15. The mochtyellid Synaptogenys rietvleiensis n. gen, n. sp. from the Soom Shale: 1, 2, photographs of holotype, which is a nearly complete jaw apparatus - (1) C853a (part), (2) C853b (counterpart); 3, SEM backscattered electron image of C853b; 4, 5, photographs of C1948a and b (part and counterpart) respectively; where the specimen has a composition of carbon (plus clay minerals) on the part (black areas), a composition of clay minerals only is seen on the counterpart (white areas); 6, SEM backscattered electron image of C1948a; 7, SEM backscattered electron image of C1948b; MI, MII and anterior teeth can be seen clearly; 8-11, C2021, compound MI, denticulated margin of MII and anterior teeth are preserved - (8) photograph of C2021a (part), (9) photograph of C2021b (counterpart), (10) SEM backscattered electron image of C2021a, (11) SEM backscattered electron image of C2021b; 12-15, C2030 one compound MI, an MII and some anterior teeth are preserved - (12) photograph of C2030a (part), (13) photograph of C2030b (counterpart), (14) SEM backscattered electron image of C2030a, (15) SEM backscattered electron image of C2030b. Scale bars in $1-3=0.5 \mathrm{~mm}, 4-7=0.25 \mathrm{~mm}$ and $8-15=0.5 \mathrm{~mm}$. 
the two palaeocontinents Baltica and Laurentia. Scolecodonts described from North America (Stauffer, 1933; Eller, 1942, 1945, 1969; Eriksson \& Bergman, 2003) can also show great similarities to those from Estonia and the neighbouring areas (Hints, 2000). Thus, it seems that oceanic basins did not constitute unpassable barriers for some polychaetes (Hints, 2000). Representatives of the Mochtyellidae and Xanioprionidae were more common in the cold-water Baltic region than in the warmerwater Laurentian region in the Mid-Late Ordovician (Hints, 1998, 2000; Eriksson \& Bergman, 2003; Hints \& Eriksson, 2007). As these two families are the only ones unequivocally recorded from the Soom Shale deposit, which has evidence of cold-water and glacial conditions, it is possible that some members of these families were more tolerant to colder conditions. However, as polychaetes are known to be sensitive to many environmental factors, other reasons may account for their occurrence in the Soom Shale.

The Soom Shale Lagerstätte scolecodonts were found on bedding planes in close proximity to chitinozoans, algae, the enigmatic needle-like organism Siphonacis, which currently is known only from the Soom Shale, and the giant elements of the conodont Promissum pulchrum Kovács-Endrödy, 1986 (Theron et al., 1990; Aldridge \& Theron, 1993; Gabbott et al., 1995). Other fossils recorded from the Soom Shale quarries include myodocopid ostracods (Gabbott et al., 2003), eurypterids (Braddy et al., 1995), naraoiids (Fortey \& Theron, 1994), chitinozoans (Cramer et al., 1974; Gabbott et al., 1998), algae (Gabbott, 1998), brachiopods (Aldridge et al., 1994), orthoconic cephalopods (Gabbott, 1999), trilobites (Moore \& Marchant, 1981) and caryocaridids (Whittle et al., 2007). Although polychaetes are generally widespread, some endemism is evident in populations (Eriksson et al., 2004). The distinctive morphology of the Soom Shale specimens may also reflect a degree of endemism. Many of the other members of the fauna discovered from the Soom Shale, such as conodonts (Theron et al., 1990; Aldridge \& Theron, 1993; Gabbott et al., 1995) also exhibit endemism.

At the present day, polychaetes have a wide variety of modes of life, including vagrant benthos, sessile, pelagic and parasitic (Glasby et al., 2000). It is unlikely that the Soom Shale specimens were infaunal, as sediment pore waters were almost certainly anoxic (Gabbott, 1998; Gabbott et al., 2001) and there is little evidence of bioturbation. However, Courtinat \& Howlett (1990) stated that bioturbation may become invisible after burial diagenesis, so a burrowing mode of life cannot be ruled out.

There may have been episodes in the deposition of the Soom Shale during which bottom waters were more oxygenated. Gabbott (1998) stated that anoxic-euxinic conditions prevailed, but there were also brief periods of oxygenation (Aldridge et al., 2001, 2006) when orthocones became colonized by epibionts while they lay exposed on the sea floor prior to burial (Gabbott, 1999). In addition, the presence of organisms, such as eurypterids, which were probably capable of swimming but lived mostly on the substrate (Braddy et al., 1995), benthic or epibenthic specimens of Lingula and a lobopod, which probably had a benthic mode of life, suggests that there were times when bottom waters were oxygenated. Therefore, the scolecodontbearing polychaete worms may have been benthic organisms. The specimens could also have been nektonic, living in the water column and this would add them to the low number of known zooplankton inhabiting this environment from the Soom Shale.

Some extant and fossil species of polychaete worms have been shown to tolerate lower oxygen concentrations, and inhospitable conditions were not continuous during the deposition of the Soom Shale. In modern environments, polychaete worms are reported from below the oxygen minimum zone and from areas with pollution (Courtinat \& Howlett, 1990). Bodergat \& Ikeya (1988) have demonstrated that the number of crustaceans diminishes in less oxygenated waters as a result of poor tolerance for variations in oxygen content, whereas polychaete worms are still present. Polychaete worms have also been reported from dysaerobic environments in the French black shales of the Toarcian, Kimmeridgian and Cenomanian-Turonian boundary interval, where the specimens include dorvelleids and mochtyellids (Courtinat \& Howlett, 1990). Previous to this, Mochtyella had been reported only from the Palaeozoic. Courtinat \& Howlett (1990) postulated that the Genus Mochtyella survived by adapting to extreme environments of low dissolved oxygen content, of great depth or both. Therefore, it is possible that the Soom Shale mochtyellids were also adapted to a low oxygen environment, explaining their domination of the polychaete fauna.

\section{ACKNOWLEDGEMENTS}

The authors acknowledge O. Hints for recommendations on an earlier draft and thank N. Thomas for advice. R. N. Wilson and M. A. Purnell provided technical guidance and support. The comments and suggestions of M. Eriksson and C. F. Bergman greatly enhanced the manuscript. RJW acknowledges a NERC studentship (NER/S/A/2003/11281); collecting was funded by research grants from NERC (GR3/10177 to RJA) and from the National Geographic Society (6715-00 to RJA). Mr and Mrs J. N. Nieuwoudt from Keurbos Farm kindly allowed access to the fossil locality. The Council for Geoscience, South Africa, provided logistical support. The excavation permit (No. 200511-002) for this work was issued by the Provincial Heritage Authority. The South African Heritage Resources Agency (SAHRA, National Heritage Authority) was responsible for authorizing the export permit to allow for the study of the fossil material in the UK.

\section{Manuscript received 23 February 2008 Manuscript accepted 6 September 2008}

\section{REFERENCES}

Aldridge, R.J. \& Theron, J.N. 1993. Conodonts with preserved soft tissues from a new Ordovician Konservat-Lagerstätte. Journal of Micropalaeontology, 12: 113-117.

Aldridge, R.J., Theron, J.N. \& Gabbott, S.E. 1994. The Soom Shale: a unique Ordovician horizon in South Africa. Geology Today, 10: 218-221.

Aldridge, R.J., Gabbott, S.E. \& Theron, J.N. 2001. The Soom Shale. In: Briggs, D.E.G. \& Crowther, P.R. (Eds), Palaeobiology II. Blackwell Science, Oxford, 340-342.

Aldridge, R.J., Gabbott, S.E., Siveter, L.J. \& Theron, J.N. 2006. Bromalites from the Soom Shale Lagerstätte (Upper Ordovician) of South Africa: palaeoecological and palaeobiological implications. Palaeontology, 49: 857-871.

Bergman, C. 1979. Polychaete jaws. In: Jaanusson, V., Laufeld, S. \& Skoglund, R. (Eds), Lower Wenlock faunal and floral dynamics- 
vattenfallet section, Gotland. Sveriges Geologiska Undersökning, C762: 92-102.

Bergman, C.F. 1989. Silurian paulinitid polychaetes from Gotland Fossils and Strata, 25: 1-128.

Bergman, C.F. 1995. Symmetroprion spatiosus (Hinde), a jawed polychaete showing preference for reef environments in the Silurian of Gotland. GFF, 117: 143-150.

Beuf, S., Biju-Duval, B., De Charpal, O., Rognon, P., Gariel, O. \& Bennacef, A. 1971. Les grès du Paléozö̈que inférieur au Sahara. Editions Technip, Paris, 464pp.

Bodergat, A.M. \& Ikeya, N. 1988. Distribution of Recent Ostracoda in Ise and Mikawa Bays, pacific coast of central Japan. In: Hanai, T., Ikeya, N. \& Ishizaki, K. (Eds), Evolutionary Biology of Ostracoda Its Fundamentals and Applications. Proceedings of the Ninth International Symposium on Ostracoda. Elsevier, Tokyo, 413-428.

Braddy, S.J., Aldridge, R.J. \& Theron, J.N. 1995. A new eurypterid from the Late Ordovician Table Mountain Group, South Africa. Palaeontology, 38: 563-581.

Cocks, L.R.M. \& Torsvik, T.H. 2002. Earth geography from 500 to 400 million years ago: a faunal and palaeomagnetic review. Journal of the Geological Society, London, 159: 631-644.

Courtinat, B. \& Howlett, P. 1990. Dorvelleids and arabellids (Annelida) as indicators of dysaerobic events in well-laminated non-bioturbated deposits of the French Mesozoic. Palaeogeography, Palaeoclimatology, Palaeoecology, 80: 145-151.

Cramer, F.H., Rust, I.C. \& Diez De Cramer, M.D.C.R. 1974. Upper Ordovician chitinozoans from the Cedarberg Formation of South Africa. Preliminary note. Geologische Rundschau, 63: 340-345.

Dales, R.P. 1963. Annelids. Hutchinson University Library, London, 200pp.

Edgar, D.R. 1984. Polychaetes of the Lower and Middle Paleozoic: a multi-element analysis and phylogenetic outline. Review of Palaeobotany and Palynology, 43: 225-284.

Ehlers, E. 1864-8. Die Borstenwürmer (Annelida Chaetopoda) nach systematischen und anatomischen Untersuchungen dargestellt. Wilhelm Engelmann, Leipzig, 748pp.

Eller, E.R. 1942. Scolecodonts from the Erindale, Upper Ordovician, at Streetsville, Ontario. Annals of the Carnegie Museum, 29: 241-270.

Eller, E.R. 1945. Scolecodonts from the Trenton Series (Ordovician) of Ontario, Quebec, and New York. Annals of the Carnegie Museum, 30: 119-212.

Eller, E.R. 1969. Scolecodonts from well cores of the Maquoketa Shale, Upper Ordovician, Ellsworth County, Kansas. Annals of the Carnegie Museum, 41: 1-17.

Eriksson, M. 1997. Lower Silurian polychaetaspid polychaetes from Gotland, Sweden. GFF, 119: 213-230.

Eriksson, M. 2001. Silurian ramphoprionid polychaetes from Gotland, Sweden. Journal of Palaeontology, 75: 993-1015.

Eriksson, M. 2003. Late Ordovician polychaetaspid polychaete annelids from the type Cincinnatian region, USA. In: Albanesi, G.L., Beresi, M.S. \& Peralta, S.H. (Eds), Ordovician of the Andes. INSUGEO, Serie Correlación Geológica, 17: 289-293.

Eriksson, M. \& Bergman, C.F. 2003. Late Ordovician jawed polychaete faunas of the type Cincinnatian region, U. S. A. Journal of Paleontology, 77: 509-523.

Eriksson, M.E., Bergman, C.F. \& Jeppsson, L. 2004. Silurian scolecodonts. Review of Palaeobotany and Palynology, 131: 269-300.

Fortey, R.A. \& Cocks, R.M. 2003. Palaeontological evidence bearing on global Ordovician-Silurian reconstructions. Earth-Science Reviews, 61: $245-307$.

Fortey, R.A. \& Theron, J.N. 1994. A new Ordovician arthropod, Soomaspis, and the agnostid problem. Palaeontology, 37: 841-861.

Gabbott, S.E. 1998. Taphonomy of the Soom Shale Lagerstätte: an example of soft tissue preservation in clay minerals. Palaeontology, 41: 631-667.

Gabbott, S.E. 1999. Orthoconic cephalopods and associated fauna from the Late Ordovician Soom Shale Lagerstätte, South Africa. Palaeontology, 42: 123-148.

Gabbott, S.E., Aldridge, R.J. \& Theron, J.N. 1995. A giant conodont with preserved muscle tissue from the Upper Ordovician of South Africa. Nature, 374: 800-803.
Gabbott, S.E., Aldridge, R.J. \& Theron, J.N. 1998. Chitinozoan chains and cocoons from the Upper Ordovician Soom Shale Lagerstätte, South Africa: implications for affinity. Journal of the Geological Society, London, 155: 447-452.

Gabbott, S.E., Norry, M.J., Aldridge, R.J. \& Theron, J.N. 2001. Preservation of fossils in clay minerals; a unique example from the Upper Ordovician Soom Shale, South Africa. Proceedings of the Yorkshire Geological Society, 53: 237-244.

Gabbott, S.E., Siveter, D.J., Aldridge, R.J. \& Theron, J.N. 2003. The earliest myodocopes: ostracodes from the late Ordovician Soom Shale Lagerstätte of South Africa. Lethaia, 36: 151-160.

Glasby, C.J. \& Alvarez, B. 1999. Distribution patterns and biogeographic analysis of Austral Polychaeta (Annelida). Journal of Biogeography, 26: 507-533.

Glasby, C.J., Hutchings, P.A., Fauchald, K., Paxton, H., Rouse, G.W., Watson Russell, C. \& Wilson, R.S. 2000. Class Polychaeta. In: Beesley, P.L., Ross, G.J.B. \& Glasby, C.J. (Eds), Polychaetes and allies: The southern synthesis. Fauna of Australia, vol 4A. Polychaeta, Myzostomida, Pogonophora, Echiura, Sipuncula. CSIRO Publishing, Melbourne, 1-296.

Gray, J., Theron, J.N. \& Boucot, A.J. 1986. Age of the Cedarberg Formation, South Africa and early land plant evolution. Geological Magazine, 123: 445-454.

Grube, A.E. 1850. Die Familien der Anneliden. Archiv für Naturgeschichte, Berlin, 16: 249-364.

Hints, O. 1998. Late Viruan (Caradoc) polychaete jaws from North Estonia and the St. Petersburg region. Acta Palaeontologica Polonica, 43: 471-516.

Hints, O. 1999. Two new polychaetes families from the Upper Ordovician of Estonia. Palaeontology, 42: 897-906.

Hints, O. 2000. Ordovician eunicid polychaetes of Estonia and surrounding areas: review of their distribution and diversification. Review of Palaeobotany and Palynology, 113: 41-55.

Hints, O. \& Eriksson, M.E. 2007. Diversification and biogeography of scolecodont-bearing polychaetes in the Ordovician. Palaeogeography, Palaeoclimatology, Palaeoecology, 245: 95-114.

Kielan-Jaworowska, Z. 1961. On two Ordovician polychaete jaw apparatuses. Acta Palaeontologica Polonica, 6: 237-259.

Kielan-Jaworowska, Z. 1962. New Ordovician genera of polychaete jaw apparatuses. Acta Palaeontologica Polonica, 7: 291-332.

Kielan-Jaworowska, Z. 1966. Polychaete jaw apparatuses from the Ordovician and Silurian of Poland and comparison with modern forms. Palaeontologica Polonica, 16: 1-152.

Kovács-Endrödy, E. 1986. The earliest known vascular plant, or a possible ancestor of vascular plants in the flora of the Lower Silurian Cedarberg Formation, Table Mountain Group, South Africa. Annals of the Geological Survey of South Africa, 20: 93-118.

Kozłowski, R. 1956. Sur quelques appareils masticateurs des Annélides Polychètes Ordoviciens. Acta Palaeontologica Polonica, 1: $165-210$.

Lamarck, J.P. de 1818. Histoire Naturelle des animaux sans vertèbres Vol. 5. Déterville, Paris, 612pp.

Martinsson, A. 1960. Two assemblages of polychaetes jaws from the Silurian of Gotland. Bulletin of the Geological Institutions of the University of Uppsala, 39: 1-8.

Mierzejewski, P. \& Mierzejewska, G. 1975. Xenognath type of polychaete jaw apparatuses. Acta Palaeontologica Polonica, 20: 437-444.

Moore, A.E. \& Marchant, J.W. 1981. A preliminary note on two trilobites from the Soom Member, Table Mountain Group. Transactions of the Geological Society of South Africa, 84: 87-89.

Nakrem, H.A., Szaniawski, H. \& Mørk, A. 2001. Permian-Triassic scolecodonts and conodonts from the Svalis Dome, central Barents Sea, Norway. Acta Palaeontologica Polonica, 46: 69-86.

Paxton, H. 1986. Generic revision and relationships of the Family Onuphidae (Annelida: Polychaeta). Records of the Australian Museum, 38: 1-74.

Smith, A.G. 1997. Estimates of the Earth's spin, geographic axis relative to Gondwana from glacial sediments and paleomagnetism. EarthScience Reviews, 42: 161-179.

Šnajdr, M. 1951. On errant Polychaeta from the Lower Paleozoic of Bohemia. Sbornik Geological Survey Czechoslovakia, 18: 1-156. 
Stauffer, C.R. 1933. Middle Ordovician Polychaeta from Minnesota. Bulletin of the Geological Society of America, 44: 1173-1218.

Sutcliffe, O.E., Dowdeswell, J.A., Whittington, R.J., Theron, J.N. \& Craig, J. 2000. Calibrating the Late Ordovician glaciation and mass extinction by the eccentricity cycles of Earth's orbit. Geology, 28: 967-970.

Szaniawski, H. 1970. Jaw apparatuses of the Ordovician and Silurian polychaetes from the Mielnik borehole. Acta Palaeontologica Polonica, 15: 445-478.

Szaniawski, H. 1996. Scolecodonts. In: Jansonius, J. \& McGregor, D.C. (Eds), Palynology: principles and applications, 1. American Association of Stratigraphic Palynologists Foundation, Texas, 337-354.

Szaniawski, H. \& Wrona, R.M. 1973. Polychaete jaw apparatuses and scolecodonts from the Upper Devonian of Poland. Acta Palaeontologica Polonica, 18: 223-267.

Theron, J.N. \& Thamm, A.G. 1990. Stratigraphy and Sedimentology of the Cape Supergroup in the Western Cape. Guidebook Geocongress 1990. Geological Society of South Africa, South Africa, 64pp.
Theron, J.N., Rickards, R.B. \& Aldridge, R.J. 1990. Bedding plane assemblages of Promissum pulchrum, a new giant Ashgill conodont from the Table Mountain Group, South Africa. Palaeontology, 33: 359-378.

Voss-Foucart, M.F., Fonze-Vignaux, M.T. \& Jeuniaux, C. 1973. Systematic characters of some annelid polychaetes at the level of the chemical composition of the jaws. Biochemical Systematics and Ecology, 1: 119-122.

Whittle, R.J., Gabbott, S.E., Aldridge, R.J. \& Theron, J.N. 2007. Taphonomy and palaeontology of a Late Ordovician caryocaridid from the Soom Shale Lagerstätte, South Africa. Palaeogeography, Palaeoclimatology, Palaeoecology, 251: 383-397.

Young, G.M., Minter, W.E.L. \& Theron, J.N. 2004. Geochemistry and palaeogeography of Upper Ordovician glaciogenic sedimentary rocks in the Table Mountain Group, South Africa. Palaeogeography, Palaeoclimatology, Palaeoecology, 214: 323-345. 